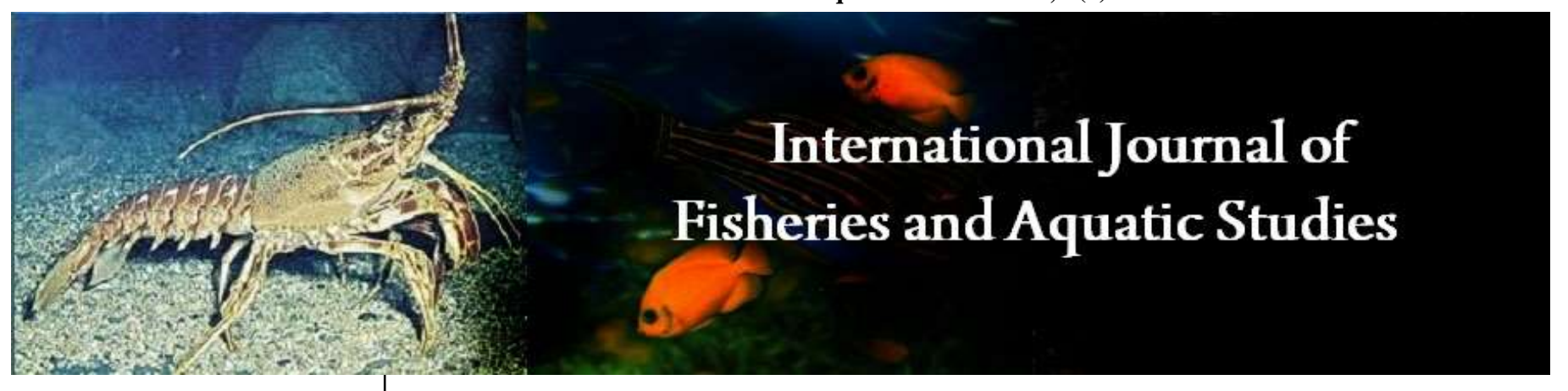

E-ISSN: 2347-5129

P-ISSN: 2394-0506

(ICV-Poland) Impact Value: 5.62

(GIF) Impact Factor: 0.549

IJFAS 2021; 9(1): 47-51

(C) 2021 IJFAS

www.fisheriesjournal.com

Received: 16-11-2020

Accepted: 22-12-2020

Kélig Mahé

IFREMER, Centre Manche-mer

du Nord, Laboratoire Ressources

Halieutiques, 150 quai

Gambetta, BP, Boulogne

Surmer, France

Elise Bellamy

IFREMER, MARBEC, UMR

IRD-CNRS-UM-IFREMER

9190, Laboratoire,

Environnement Ressources

Languedoc Roussillon, 8 Avenue

Jean Monnet, CS, Sète Cedex,

France

Frank D'Amico

CNRS/Univ Pau \& Pays Adour,

Laboratoire de Mathématiques et

de leurs Applications de Pau-

Fédération MIRA, UMR 5142,

E2S UPPA, Anglet, France

Nathalie Caill-Milly

IFREMER, LITTORAL,

Laboratoire Environnement

Ressources d'Arcachon, 1 allée du

Parc Montaury, Anglet, France

Corresponding Author:

Kélig Mahé

IFREMER, Centre Manche-mer

du Nord, Laboratoire Ressources

Halieutiques, 150 quai

Gambetta, BP, Boulogne

Surmer, France

\section{In situ fast marking study of manila clams (Ruditapes philippinarum)}

\author{
Kélig Mahé, Elise Bellamy, Frank D’Amico and Nathalie Caill-Milly
}

DOI: $\underline{\text { https://doi.org/10.22271/fish.2021.v9.i1a.2387 }}$

\section{Abstract}

Arcachon Bay, in the southern Bay of Biscay, is the first French production area of Manila clam (Ruditapes philippinarum) with an annual commercial fisheries production around 400 tons in recent years. This bivalve mollusc was introduced into the bay in the 1980s for aquaculture purpose and quickly succeeded in natural settlement so that its high market value led to the progressive establishment of a perennial fishery from the mid-1990s. Local management plans applied to this species are based on a licensing system for the commercial, protected fishery areas and days of prohibited fishing for both commercial and recreational fishermen. A minimum catch size is also prescribed by European regulation, and so growth rates are an important matter in this context. This work focuses on studying shell growth from the recapture of shells, previously marked using a chemical marker (calcein) and then grown in natural conditions, and was performed in order to determine shell growth patterns. Manila clams were marked by immersion in situ in seawater containing calcein. In order to study the limitations of calcein on the mark readability in situ and manila clam mortality, various exposure times, from 30 minutes to 1 hour, and concentrations, from $50 \mathrm{mg} . \mathrm{L}^{-1}$ to $200 \mathrm{mg} . \mathrm{L}^{-1}$ were tested. After a period of 35 days, 69 growth micro-increments were observed, and, it was found that increment deposition in manila clams occurs with a tidal periodicity. Moreover, this study showed that a method for fast-marking of manila clams, and potentially other species, is feasible in situ.

Keywords: Calcein, In-situ marking, ruditapes philippinarum, bivalve mollusks, fisheries

\section{Introduction}

Growth information is necessary for population structure assessment of economically important and exploited bivalve species. The Manila clam Ruditapes philippinarum (Adams and Reeve 1850), endemic to Indo-Pacific waters, is one of the most commercially exploited bivalve molluscs in the world. Introduced in different geographical areas, the Manila clam is now widely distributed along the Pacific coast of the United States, the European Atlantic coast, the Adriatic and Aegean seas and the Indo-Pacific region [1]. This species was introduced into Arcachon Bay at the beginning of the 1980s for aquaculture purposes ${ }^{[2]}$ and it rapidly colonised all intertidal flats of the lagoon. Arcachon Bay has the highest catch levels in French waters at around 400 tonnes per year ${ }^{[3,4]}$. Current methods for age estimation of bivalves rely on quantification of growth rings on the shell surface. However, for this species, it is not possible to distinguish external growth increments due to typically slow growth in winter and also from occasionally unfavourable summer conditions (e.g hypoxia). Therefore, establishing a fixed, internal shell mark and could potentially be used to investigate growth. Several chemical markers have been tested to validate animal age through the deposition of an internal growth increment, as the organisms exposed to chemical markers incorporate it into the growing calcified structures. An efficient marker must present certain characteristics: being harmless to the organisms, detectable, easy-to-use, long-lasting etc. Several markers have been used and experience has demonstrated that marker suitability is species-specific ${ }^{[5,6]}$. Among fluorochromes, calcein has presented little toxicity and reliable marking quality ${ }^{[6,7]}$. In the present study, the potential of in-situ marking with very short exposure time to the fluorochrome calcein has been investigated in $R$. philippinarum, specifically in relation to mark quality and mortality rate, depending on concentration and exposure time. Determination of the periodicity of shell growth ring production typically is accomplished by marking shells in the laboratory and then the animals return to the wild. This long manipulation of the shellfish increases the stress level and consequently the mortality level of the organisms. 
Moreover, in the specific context of Arcachon Bay characterized by a lot of small areas production, it is very difficult to realize one 'traditional' marking study in the laboratory across this entire of these areas without to introduce the bias in the methodology between different locations. Consequently, this In-situ fast marking study of Manila Clams wants to answer at two questions:

- Is it possible to realize In-situ fast marking study in thirty minutes to follow the differential growth of Manila Clams in many locations during the same environmental conditions and to limit the potential effects of the marking step on the growth of this shellfish?

- The tidal deposition of growth ring: is it clearly present from the cold shock as observed by Richardson ${ }^{[8]}$ in Wales or from calcein-marked individuals during 3 hours used the benthic chamber in the Gulf of Morbihan ${ }^{[9]}$ ?

\section{Materials and Methods}

\subsection{Study site}

Arcachon Bay is a $156 \mathrm{~km}^{2}$ semi-sheltered lagoon on the south-west coast of France. Mostly composed of tidal flats (110 km long within the inner lagoon); this mesotidal system is characterized by a sediment composition ranging from mud to muddy sands and colonized by vast Zostera noltii seagrass meadows. The bay is influenced by external neritic waters and by continental inputs ${ }^{[10]}$, and presents a semidiurnal macrotidal rhythm. The manila clam is, in terms of biomass, the dominant species of these intertidal flats $[10,11]$. In February 2011, 80 living specimens were collected in the same geographical area. The samples represented all $R$. philippinarum length classes which were between 10.4 and $45.0 \mathrm{~mm}$ (length defined as the longest distance from front edge to back edge).

\subsection{Staining experiment}

The manila clams were divided into 8 groups of 10 specimens, each with a similar size distribution (from $10 \mathrm{~mm}$ to $45 \mathrm{~mm}$ in length). The clams were marked by immersion in situ in seawater containing calcein (CAS 1461-15-0) (Fig. 1). In order to study the limits of calcein on the mark readability in situ and the manila clam mortality, various calcein exposure times, from 30 minutes to 1 hour, and concentrations, from $50 \mathrm{mg} . \mathrm{L}^{-1}$ to $200 \mathrm{mg} . \mathrm{L}^{-1}$ have been tested. 80 individuals were marked during 30 minutes with the calcein concentrations of $50 \mathrm{mg} . \mathrm{L}^{-1}, 100 \mathrm{mg} . \mathrm{L}^{-1}$ and 200 $\mathrm{mg} . \mathrm{L}^{-1}$, and during 1 hour for only the calcein concentrations of $100 \mathrm{mg} . \mathrm{L}^{-1}$ with 2 replicates for each tagging condition (i.e. exposure time-calcein concentration). After the marking procedure, all manila clam groups were replaced in an experimental structure. These cages were built as a cube with a side length of $50 \mathrm{~cm}$ to obtain a density equal to that observed and a depth covering the life depth of this species, living mostly in the first ten centimetres of the substratum ${ }^{[12]}$ (Fig. 1).

\subsection{Detection and periodicity of growth mark}

After a period of 35 days, all manila clams from each group were recaptured and sacrificed. Empty shells were cleaned and oven-dried at $30^{\circ} \mathrm{C}$ for $48 \mathrm{~h}$ to enable the shell inclusion into the resin. To analyse internal micro-growth increments, shells were embedded in thermoplastic resin then transversely cut along the maximum growing axis (from the umbo to the ventral margin) using a precision saw with a blade thickness of $0.25 \mathrm{~mm}$ (Fig. 2). The thin sections (thickness of $0.2 \mathrm{~mm}$ ) were first mounted in slides, where were then ground on a lapidary wheel using 600-grade grit followed by 1000 -grade grit waterproof abrasive paper, and polished with wrapping film sheets (3M, St. Paul, MN, USA) using grits of 2000, 4000, 8000, 10000,15000 and 40000 grades consecutively on both sides. Polished surfaces were examined by stereomicroscope for scratches using reflecting light, and polishing was repeated until all visible scratches were removed.

Manila clams marked with calcein were observed through Zeiss motorized microscope combined to motorized stage, capable rebuild one mosaic image from many calibrated images and capable of fluorescent imaging with wavelengths of 460-490 $\mathrm{nm}$. Image analyses were carried out by means of numerical camera (Hamamatsu) dedicated to the fluorescent light and piloted by the TNPC software (Calcified Structure Digital Processing, www.tnpc.fr) in order to determine the number of increments mineralized during the 35 days of the experiment. To identify the growth increments, two experts analysed the shell area between the fluorescent band along the growth axis parallel to the growth axis. Moreover, grey levels have been extracted by image analysis measuring the luminous intensity of each pixel along this growth axis. These measurements and its location along the growth axis were used to identify the limits between each opaque band and each hyaline band, reflecting each one growth increment.

\section{Results}

No mortality occurred during the experiment in any of the 8 groups. Thus, calcein marker treatments proved not to be lethal at maximal concentrations of $200 \mathrm{mg} . \mathrm{L}^{-1}$ and for the longest exposure time of 1 hour. Calcein produced a clearly visible fluorescent growth band in shells at all concentrations and exposure time (Fig. 2). Calcein fluorescent bands were easily identified in all recovered manila clams from 30 minutes exposure with a concentration of $100 \mathrm{mg} . \mathrm{L}^{-1}$ (Fig. 2). The mark intensity of fluorescence essentially depends on the calcein concentration; the influence of exposure time appears limited (Tab. 1).

Single marked increments have been identified by fluorescence each time the experiment was successful and the mark was distinguishable almost along the whole shell, from the ventral margin to the hinge, suggesting uptake along the whole mantle edge. Additionally, distinct growth lines are recognized under fluorescence microscopy (Fig. 3). The experts, with image analysis, identified 69 growth microincrements on the shell from the calcein band to the edge during the experiment relevant to the period of 35 days and 69 tides (Fig. 3). Consequently, it is established that increment deposition in manila clams occurs with a tidal periodicity.

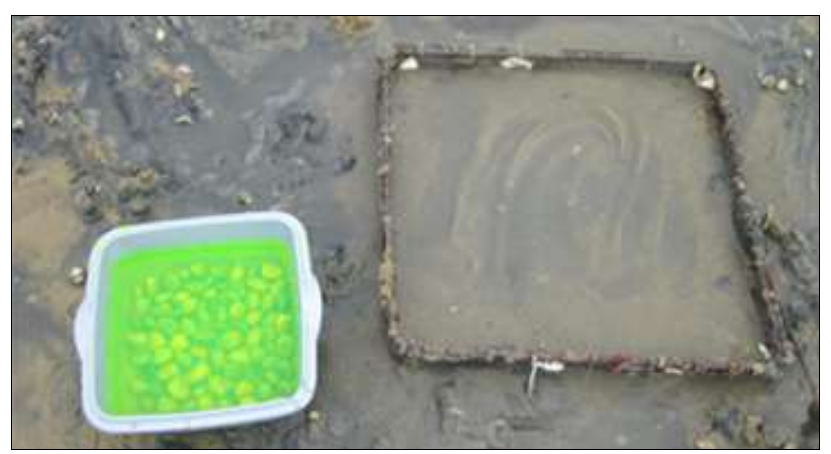

Fig 1: In situ fast marking study of Manila Clam with the calcein fluorochrome dye. 


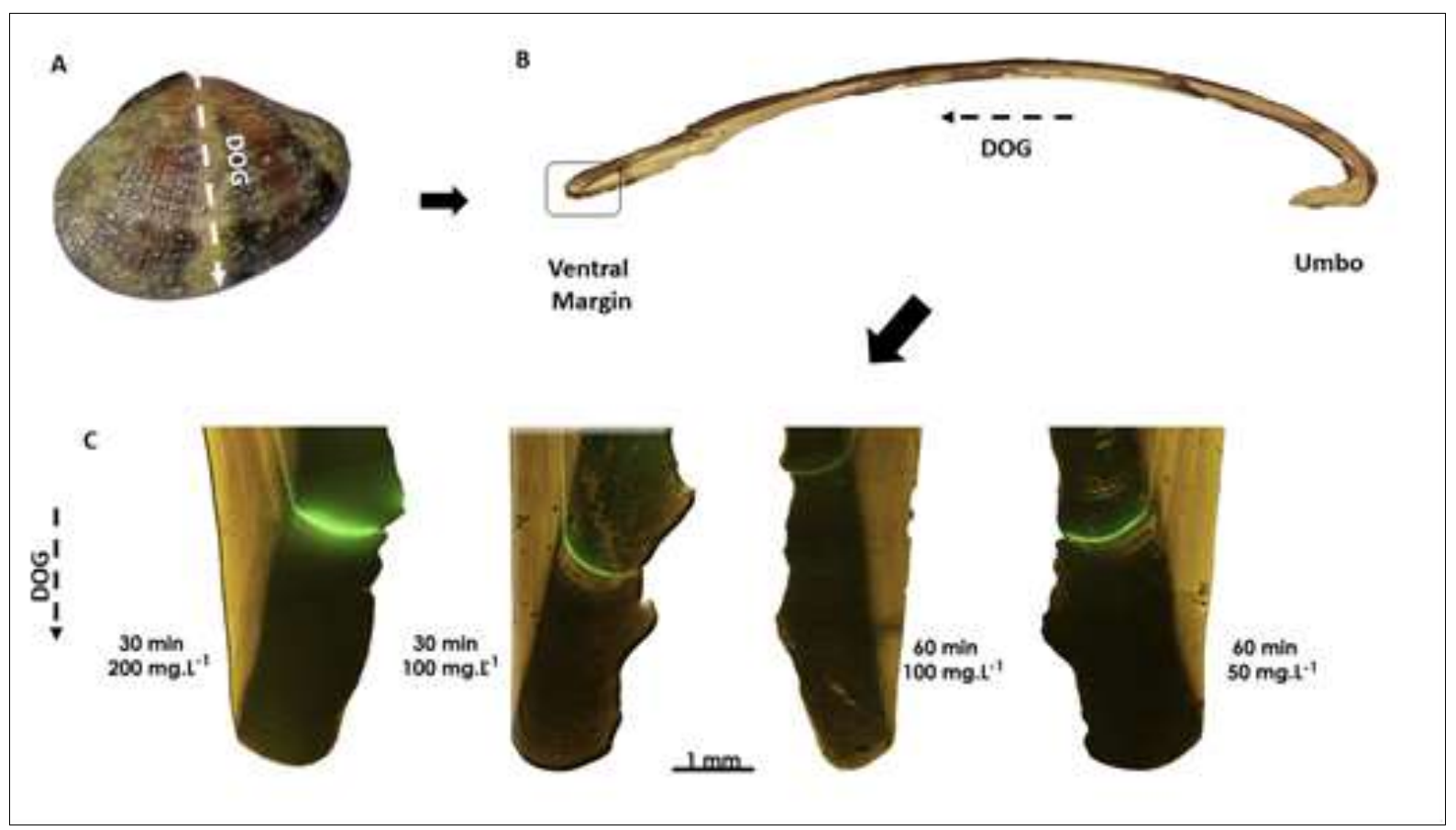

Fig 2: A Valve of Manila Clam with the line which represents the direction of growth (DOG); B) Thick section of shell (thickness of $0.2 \mathrm{~mm}$ ); C) Ventral margin of a calcein-marked shell with a fluorescent mark (Calcein exposure time and concentration are indicated for each staining experiment)

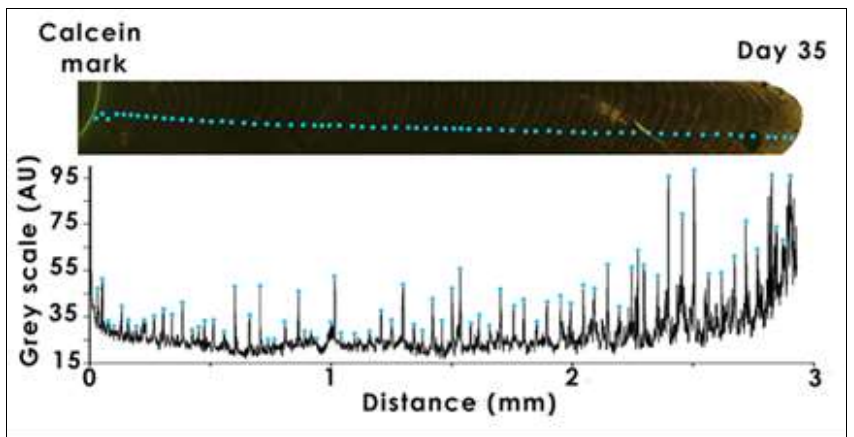

Fig 3: Magnification of a ventral margin in Manila clam: green fluorescent mark produced following 30 minutes calcein solution exposure (100 mg L-1) and observed growth increments before and after marking. Along a growth axis, grey levels have been measured (AU: arbitrary unit) and each grey peak is identified (blue circle) as the limit between each opaque band and each hyaline band, reflecting each one growth increment.

Table 1: Quality marking (Mark intensity in arbitrary units, AU) and mortality according to calcein concentration and exposure time.

\begin{tabular}{|c|c|c|c|c|}
\hline Groups & $\begin{array}{c}\text { Concentration } \\
(\mathrm{mg} \text { L-1) }\end{array}$ & $\begin{array}{c}\text { Exposure } \\
\text { time }(\mathrm{min})\end{array}$ & $\begin{array}{c}\text { Mortality } \\
(\%)\end{array}$ & $\begin{array}{c}\text { Mark } \\
\text { intensity } \\
(\mathrm{AU})\end{array}$ \\
\hline 1 & 200 & 30 & 0 & 122 \\
\hline 2 & 100 & 30 & 0 & 87 \\
\hline 3 & 100 & 60 & 0 & 83 \\
\hline 4 & 50 & 30 & 0 & 68 \\
\hline
\end{tabular}

\section{Discussion}

In recent studies on other bivalve growth, calcein exposure time and concentration used varied from 3 to 72 hours and from 10 to $500 \mathrm{mg} . \mathrm{L}^{-1}[6,13,14,15,16,17]$. Several studies on bivalve growth have suggested that calcein fluorochrome exhibits little toxicity $[6,13,14,16,18,19]$. Similarly, in this work, the range of calcein concentrations used (from 50 to 200 mg. $\mathrm{L}^{-1}$ ) had no lethal effect for all clam length classes during the experiment. In the same way, to limit the effects of stress to the clams during calcein marking, In situ experiments have been performed. A marking study of subtidal populations of manila clams in the north of the Bay of Biscay was realised in 3 hours with the calcein concentration of $150 \mathrm{mg} . \mathrm{L}^{-1}$ using benthic chambers ${ }^{[9]}$. Our study showed in 30 minutes, in situ exposure is enough to realise an effective shell mark on the species. Consequently, in situ calcein marking is efficient and has a time benefit allowing work during a single tidal period and also limits the stress to the manila clams caused by manipulation.

Manila clam's shell is composed of two aragonitic layers, an inner homogeneous layer and an outer prismatic layer. Our images analysis showed 69 growth micro-increments within the 35 days. Consequently, this periodicity was considered to be tidal. The result corroborated other studies on this species $[8,9,20]$ and confirms the tidal regime as the main environmental factor dictating shell growth in intertidal habitats ${ }^{[21]}$. As shell growth of bivalves is limited to high tides ${ }^{[22,23]}$, during aerial exposure at low tide, the animals are forced to keep their valves tightly closed, and retract the mantle into the shell, leading to shell growth cessation and the formation of a growth-check line ${ }^{[9,20,24,25]}$. Other intertidal bivalve species have presented a similar tidal periodicity of growth micro-increments in Clinocardium nuttalli ${ }^{[22]}$, Cerastoderma edule ${ }^{[26,27]}$, Tapes philippinarum ${ }^{[8]}$, Chione fluctifraga and C. cortezi [28], Phacosoma japonicum [29], Mesodesma donacium [30], Phacosoma japonicum [31] and Saxidomus gigantea [32], Anadara granosa ${ }^{[33]}$. However, it was not the case for all bivalves, as daily $[34,35,36,37,38]$ or

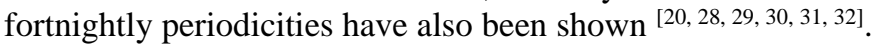
These periodicity growth increment mainly could be explained by the hydric stress differences due to the location in the neritic zone (subtidal versus intertidal) and the emersion time in the intertidal area.

\section{Conclusions}

This preliminary study showed that it was possible to realise the relatively simple in situ marking of bivalves during a 
single tide with no observed mortality. This type of approach could be applied to the other bivalve species.

\section{Acknowledgements}

We are grateful to Christian Cantin from Ifremer Arcachon who died suddenly in 2011, to Inès Camberon student and Yannick Castaing professionnal fisherman for their help in the collection of the clams and their assistance during the experiment on the field. We would especially thank Mark Etherton, a native English speaker, for his valuable help in correcting this manuscript.

\section{Authors' contributions}

FA and NCM supervised the study design and the in situ experiment. EB analysed data. KM interpreted the data and wrote the manuscript. All authors read and approved the final manuscript.

\section{References}

1. Jensen AC, Humphreys J, Caldow RWG, Grisley C, Dyrynda PEJ. Naturalization of the Manila clam (Ruditapes philippinarum), an allien species, and establishment of a clam fishery within Poole Harbour, Dorset. J. Mar. Biol. Assoc. U.K 2004;84:1069-1073. https://doi.org/10.1017/S0025315404010446h

2. Goulletquer P, Lombas I, Prou J. Influence du temps d'immersion sur l'activité reproductrice et sur la croissance de la palourde japonaise Ruditapes philippinarum et l'huître japonaise Crassostrea gigas. Haliotis 1987;16:453-462.

3. Caill-Milly N, Bru N, Mahé K, Borie K, D'Amico F. Shell Shape Analysis and Spatial Allometry Patterns of Manila Clam (Ruditapes philippinarum) in a Mesotidal Coastal Lagoon. J. Mar. Biol 2012,1-11. https://doi.org/110.1155/2012/281206

4. Sanchez F, Caill-Milly N, Lissardy M. Campagne d'évaluation du stock de palourdes du bassin d'Arcachon. Année 2018. R.ODE/LITTORAL/LER AR 18.015.

5. Bashey F. A comparison of the suitability of alizarin red $\mathrm{S}$ and calcein for inducing a non-lethally detectable mark in juvenile guppies. T Am. Fish. Soc 2004;133:15161523. https://doi.org/10.1577/T03-073.1

6. Riascos J, Guzma N, Laudien J, Heilmayer O, Oliva M. Suitability of three stains to mark shells of Concholepas concholepas (Gastropoda) and Mesodesma donacium (Bivalvia). J Shellfish Res 2007;20:43-49. https://doi.org/10.2983/07308000(2007)26[43:SOTSTM]2.0.CO;2

7. Mckinnon JF. Studies of the age, growth and shell increment patterns in the New Zealand cockle (Austrovenus stutchburyi). $\mathrm{PhD}$ thesis. University of Otago, New Zealand 1996.

8. Richardson CA. Tidal bands in the shell of the clam Tapes philippinarum, (Adams \& Reeve, 1850). Proc. R. Soc. Lond. B Biol. Sci 1987;230:367-387. https://doi.org/10.1098/rspb.1987.0025

9. Poulain NC, Lorrain A, Flye-Sainte-Marie J, Amice E, Morize E, Paulet YM. An environmentally induced tidal periodicity of microgrowth increment formation in subtidal populations of the clam Ruditapes philippinarum. J. Exp. Mar. Biol. Ecol 2011;397:58-64. https://doi.org/10.1016/j.jembe.2010.11.001

10. Dang C. Dynamique des populations de palourdes japonaises (Ruditapes philippinarum) dans le bassin
d'Arcachon, conséquences sur la gestion des populations exploitées. PhD thesis. University of Bordeaux I, France 2009.

11. Blanchet H, De Montaudouin X, Lucas A, Chardy P. Heterogeneity of macrozoobenthic assemblages within a Zostera noltii seagrass bed: diversity, abundance, biomass and structuring factors. Estuar. Coast Shelf. S 2004;61:111-123. https://doi.org/10.1016/j.ecss.2004.04.008

12. Le Treut Y. La palourde. Anatomie - Biologie - Elevage Pêche - Consommation - Inspection sanitaire. $\mathrm{PhD}$ thesis. University of Nantes, France 1986.

13. Day RW, Williams MC, Hawkes GP. A comparison of fluorochromes for marking abalone shells. Mar. Freshwater Res 1995;46:599-605. https://doi.org/10.1071/MF9950599

14. Kaehler S, McQuaid CD. Use of the fluorochrome calcein as an in situ marker in the brown mussel Perna perna. Mar. Biol 1999;133:455-460. https://doi.org/10.1007/s002270050485

15. Clarke A, Prothero-Thomas E, Beaumont JC, Chapman AL, Brey T. Growth in the limpet Nacella concinna from contrasting sites in Antarctica. Polar Biol. 2004; 28:6271. https://doi.org/10.1007/s00300-004-0647-8

16. Thebault J, Chauvaud L, Clavier J, Fichez R, Morize E. Evidence of a 2-day periodicity of striae formation in the tropical scallop Comptopallium radula using calcein marking. Mar. Biol 2006;149:257-267. https://doi.org/10.1007/s00227-005-0198-8

17. Lucas T, Palmer PJ, Wang S, Scoones R. Marking the shell of the saucer scallop Amusium balloti for sea ranching using oxytetracycline, calcein and alizarin red $\mathrm{S}$. J Shellfish Res 2008;27(5):1183-1188. https://doi.org/10.1051/alr/2010025

18. Rowley RJ, Mackinnon DI. Use of the fluorescent marker calcein in biomineralisation studies of brachiopods and other marine organisms. Bull. Nat. Inst. Oceanogr. Fish 1995;14(2):111-120. http://dx.doi.org/10.1051/alr/2010025

19. Moran AL. Calcein as a marker in experimental studies newly-hatched gastropods. Mar. Biol 2000;137:893-898. https://doi.org/10.1007/s002270000390

20. Richardson CA. Tidally produced growth bands in the subtidal bivalve Spisula subtruncata (Da Costa). J Molluscan Stud 1988;54(1):71-82. https://doi.org/10.1098/rspb.1987.0025

21. Schone BR. The curse of physiology-challenges and opportunities in the interpretation of geochemical data from mollusk shells, Geo-Mar. Lett 2008;28:269-285. https://doi.org/10.1007/s00367-008-0114-6

22. Evans JW. Tidal growth increments in the cockle Clinocardium nuttalli. Science 1972;176:416-417. https://doi.org/10.1126/science.176.4033.416

23. Goodwin DH, Flessa KW, Schone BR, Dettman DL. Cross-Calibration of Daily Growth Increments, Stable Isotope Variation, and Temperature in the Gulf of California Bivalve Mollusk Chione cortezi: Implications for Paleoenvironmental Analysis. Palaios 2001;16:387398. https://doi.org/10.2307/3515578

24. Clark GR. Growth lines in Invertebrates skeletons. Annu. Rev. Earth Planet. Sci 1974;2:77-99. https://doi.org/10.1146/annurev.ea.02.050174.000453

25. Richardson CA, Crisp DJ, Runham NW. Tidally deposited growth bands in the shell of the common 
cockle, Cerastoderma edule (L.). Malacologia 1979;18:277-290. https://doi.org/10.1017/S0025315400052425

26. Richardson CA, Crisp DJ, Runham NW. Factors influencing shell deposition during a tidal cycle in the intertidal bivalve Cerastoderma edule. J. Mar. Biol. Assoc. U.K 1981;61:465-476. https://doi.org/10.1017/S0025315400047081

27. Mahé K, Bellamy E, Lartaud F, De Rafelis M. Calcein and manganese experiments for marking the shell of the common cockle (Cerastoderma edule): Tidal rhythm validation of increments formation. Aquat. Living Resour. 2010;23(3):239-245. https://doi.org/10.1051/alr/2010025

28. Schone BR, Goodwin DH, Flessa KW, Dettman DL, Roopnarine PD. Sclerochronology and Growth of the bivalve mollusks Chione (Chionista) fluctifraga and $\mathrm{C}$. (Chionista) cortezi in the northern Gulf of California, Mexico. Veliger 2002;45:45-54.

29. Schone BR, Tanabe K, Dettman DL, Sato S. Environmental controls on shell growth rates and $\delta 18 \mathrm{O}$ of the shallow-marine bivalve mollusk Phacosoma japonicum in Japan. Mar. Biol 2003;142:473-485. https://doi.org/10.1007/s00227-002-0970-y

30. Carre M, Bentaleb I, Blamart D, Ogle N, Cardenas F, Zevallos $\mathrm{S}$ et al. Stable isotopes and sclerochronology of the bivalve Mesodesma donacium: potential application to Peruvian paleoceanographic reconstructions. Palaeogeogr. Palaeoclimatol. Palaeoecol 2005;228:4-25. https://doi.org/10.1016/j.palaeo.2005.03.045

31. Miyaji T, Tanabe K, Schone BR. Environmental controls on daily shell growth of Phacosoma japonicum (Bivalvia: Veneridae) from Japan. Mar. Ecol. Prog. Ser 2007;336:141-150. http://hdl.handle.net/10523/3110

32. Hallmann $\mathrm{N}$, Burchell $\mathrm{M}$, Schone $\mathrm{BR}$, Irvine $\mathrm{CV}$, Maxwell D. High-resolution sclerochronological analysis of the bivalve mollusk Saxidomus gigantea from Alaska and British Columbia: techniques for revealing environmental archives and archaeological seasonality. J. Archaeol. Sci 2009;36:2353-2364. https://doi.org/10.1016/j.jas.2009.06.018

33. Mirzaei MR, Yasin Z, Tan Shau Hwai A. Periodicity and shell microgrowth pattern formation in intertidal and subtidal areas using shell cross sections of the blood cockle, Anadara granosa. Egyptian Journal of Aquatic Research https://doi.org/10.1016/j.ejar.2014.11.008

34. Rhoads DC, Pannella G. The use of molluscan shell growth patterns in ecology and paleoecology. Lethaia 1970;3:143-161. https://doi.org/10.1111/j.15023931.1970.tb01854.x

35. Clark GR. Mollusk shell: daily growth lines. Science 1968;161:800-802. https://doi.org/10.1126/science.161.3843.800

36. Clark GR. Daily growth lines in some living Pectens (Mollusca: Bivalvia), and some applications in a fossil relative: time and tide will tell. Palaeogeogr. Palaeoclimatol. Palaeoecol 2005;228:26-42. https://doi.org/10.1016/j.palaeo.2005.03.044

37. Lazareth CE, Lasne G, Ortlieb L. Growth anomalies in Protothaca thaca (Mollusca, Veneridae) shells as markers of ENSO conditions. Clim. Res 2006;30:263-269. https://doi.org/10.3354/cr030263

38. Schone BR, Giere O. Growth increments and stable isotope variation in shells of the deep-sea hydrothermal vent bivalve mollusk Bathymodiolus brevior from the North Fiji Basin, Pacific Ocean. Deep Sea Res. Part. 1 Oceanogr. Res. Pap 2005;52:1896-1910. https://doi.org/10.1016/j.dsr.2005.06.003. 